\title{
EKSISTENSI ANAK PEREMPUAN DALAM HUKUM KEWARISAN SYIAH
}

\author{
Faby Toriqirrama \\ Pascasarjana UIN Sunan Ampel Surabaya. E-Mail: \\ fabytoriqirrama@gmail.com
}

\begin{abstract}
This is a bibliographical research that discusses the justice of girls in Shi'ah inheritance system. The issue which is the subject of discussion is the position of female beirs, especially girls, who in Sunni inheritance system is not treated equally with other heirs, whether they are equal or not. Because in the Sunni inheritance system, male superiority is highly exalted. Between sons and daughters, even though they are equal in the eyes of the heir, still have an unbalanced power in veiling other heirs. Whereas in Shi'ah inheritance system, girls are positioned as equals to boys. They have the same bijab power. In addition, Presidential Instruction No. 1 of 1991 concerning Compilation of Islamic Law (KHI) also applies the principle of equality between girls and boys in terms of veiling other heirs. Nevertheless, KHI did not adopt the class system directly. However, it is explicitly stated in article 181 and article 182 that the existence of a daughter causes sibling, sibling with the same mothe or sibling with the same father does not receive part of the inheritance.
\end{abstract}

Keywords: Shi'ah inheritance system, Sunni inheritance system, and Girls.

Abstrak: Artikel ini adalah hasil penelitian pustaka yang membahas keadilan anak perempuan di dalam hukum kewarisan Syiah. Permasalahan yang menjadi pokok bahasan adalah posisi ahli waris wanita-terutama anak perempuan-yang di dalam hukum kewarisan Sunni tidak diperlakukan setara dengan ahli waris lainnya, baik yang sederajat atau tidak. Sebab di dalam hukum kewarisan Sunni, superioritas laki-laki sangat diagungkan. Antara anak laki-laki dan anak perempuan-walaupun sederajat di mata pewaris - tetap memiliki kekuatan yang tidak seimbang di dalam menghijab ahli waris yang lain. Sedangkan di dalam hukum kewarisan Syiah, anak perempuan diposisikan setara dengan anak laki-laki. Mereka memiliki kekuatan menghijab yang sama kuatnya. Selain itu, Inpres No. 1 Tahun 1991 tentang Kompilasi hukum Islam (KHI) juga menerapkan prinsip kesetaraan antara anak perempuan dengan anak lakilaki dalam hal menghijab ahli waris lainnya. Kendati demikian, KHI tidak mengadopsi sistem Kelas secara langsung. Namun, secara eksplisit tersebut di dalam pasal 181 dan pasal 182 bahwa eksistensi anak perempuan menyebabkan saudara kandung, saudara seibu, atau saudara seayah tidak menerima bagian harta waris.

Kata Kunci: Kewarisan Syiah, Kewarisan Sunni dan Anak Perempuan.

AL-HUKAMA

The Indonesian Journal of Islamic Family Law

Volume 09, Nomor 01, Juni 2019; ISSN:2089-7480 


\section{Pendahuluan}

Hukum kewarisan Islam di era sekarang, menurut pandangan penulis, tidak pernah menjadi kajian yang kontekstual dan semakin terpinggirkan. Alasan paling mendasar adalah terdapat banyak aspek yang dipandang tidak relevan ataupun out-dated. Satu hal yang paling menjadi sorotan adalah relasi antara laki-laki dan perempuan yang tidak seimbang. Di samping itu, hukum kewarisan Islam juga dianggap tidak memiliki daya praksis karena masyarakat Muslim Indonesia-terutama di daerah Jawa-lebih sepakat untuk menggunakan sistem waris adat yang membagi sama rata antara ahli waris laki-laki maupun perempuan. Dengan alasan demikian, hukum kewarisan Islam seakan gagal menghadirkan fikih yang kompatibel dengan kepentingan manusia.

Di ranah teoretis, stagnasi pemikiran tentang hukum kewarisan Islam terjadi akibat ayat-ayat waris di dalam Alquran oleh ulama ushul fikih dianggap sebagai ayat yang qath'i al-dalalah. Maksudnya, ayat tersebut menunjukkan makna yang spesifik, tidak mengandung takwil, dan tidak ada ruang untuk dimaknai selain itu. Alquran Surat al-Nisa': 11 yang di dalamnya memuat penjelasan tentang bagian anak perempuan, tergolong ke dalam ayat yang qath'i al-dalalah.1 Sehingga, tidak ada alasan untuk memperdebatkan bagian anak perempuan meski dalam konteks ruang dan waktu yang berlainan.

Ayat-ayat di dalam Alquran yang menyebut bilangan di berbagai literatur ushul fikih memang selalu dijadikan contoh ayatayat yang qath'i al-dalalah. Menurut penulis kendatipun kebenaran perhitungan itu bersifat aksiomatis (tidak memerlukan pembuktian secara empiris, namun kebenarannya disepakati oleh umat manusia di belahan dunia mana pun. Tidak mungkin kata "setengah" yang tertulis di dalam Surat al-Nisa' itu bermakna "satu" atau yang lainnya. Oleh karenanya, tidak mungkin terjadi perbedaan pendapat dalam hal bilangan.

Walaupun qath'i al-dalalah, penerapan hukum kewarisan Islam tidak berbentuk amar Tuhan yang bersifat fardu ain. Basis

1 Abd Wahab Khalaf, Ilm Ushul al-Fiqh, (Jakarta: Dar al-Kutub al-Islamiyah, 2010), 33 . 
pelaksanaannya adalah musyawarah-mufakat karena dimensinya berada dalam lingkup muamalah. Asalkan para ahli waris sudah menyetujui bagian harta waris yang ia terima maka hal tersebut dipandang sah. Kebolehan untuk tidak menerapkan hukum kewarisan Islam tersebut didasarkan pada prinsip maslahat. Sebab, justru akan berpotensi menimbulkan konflik apabila hukum kewarisan Islam tetap dipaksakan.

Jika diperinci lebih spesifik, ulama Sunni lah yang memaknai Alquran Surat al-Nisa': 11 secara apa adanya. Jika hanya terdapat anak perempuan yang berdiri sebagai ahli waris, maka maksimal ia hanya dapat memperoleh setengah bagian. Sebab hal tersebut sudah diatur di dalam nas secara qath'i. Sedangkan hal tersebut tidak berlaku di dalam hukum kewarisan Syiah. Mereka berpendapat bahwa anak perempuan bisa memperoleh seluruh harta jika ia berdiri sebagai ahli waris satu-satunya. Oleh karena itu, bagi mereka masih terbuka ruang untuk dimaknai secara kontekstual meskipun nasnya qath'i.

Namun yang perlu diluruskan adalah bangunan epistemologi hukum kewarisan Islam itu sendiri. Sebenarnya, penyematan kata "Islam" itu cakupannya luas, tetapi selama ini pembahasannya terbatas pada hukum kewarisan Sunni-terlebih mengacu pada mazhab Syafi'i saja. Hanya sedikit referensi yang berusaha merinci hukum kewarisan Islam menjadi dua fraksi besar, yakni "kewarisan Sunni" dan "kewarisan Syi'ah".2

Pemahaman hukum kewarisan Islam yang kurang komprehensif dan spesifik penulis asumsikan menjadi sebab bagi faksi feminis untuk mengkritik hukum kewarisan Islam. Bisa jadi yang dilihatnya sebagai "kewarisan Islam" adalah satu—katakanlah Sunni-dari beberapa versi hukum kewarisan Islam yang ada. Implikasinya, hukum kewarisan Islam menerima berbagai hantaman kritik karena memosisikan perempuan sebagai makhluk subordinat. Walaupun hukum kewarisan Islam sekarang dipandang lebih

2 Salah satu referensi yang mengkaji hukum kewarisan Islam dengan meyajikan analisis yang berimbang adalah Amir Syarifuddin, Hukum Kewarisan Islam, (Jakarta: Kencana, 2008). 
memperhatikan wanita yang di zaman pra-Islam, mereka bahkan tidak mempunyai hak waris sama sekali.3

Kendatipun demikian, hal tersebut belum cukup memuaskan tokoh feminis - salah satunya Amina Wadud. Di dalam bukunya, ia mengkritik porsi dua bagi laki-laki dan satu bagi perempuan yang dianggapnya sebagai salah satu "versi" pembagian waris. Namun "versi" yang ia maksudkan adalah sesuatu yang kontekstual. Artinya, porsi ahli waris perempuan itu dapat berubah-ubah berdasarkan kondisi ketika ahli waris perempuan tersebut mewarisi bersama ahli waris lain.4 Namun ia luput membahas "versi" hukum kewarisan Islam dalam mazhab atau aliran lain.

Lantas benarkah postulat bahwa dari berbagai versi hukum kewarisan Islam yang ada, seluruhnya memandang wanita secara subordinat sehingga tidak mampu berdiri sejajar dengan laki-laki? Untuk itu, penulis mencoba mendalami salah satu versi hukum kewarisan Islam yang dianut kelompok Syiah Ithna Asy'ariah. Kendatipun di dalam aliran Syiah sendiri masih terdapat perbedaan penerapan hukum kewarisan Islam. Misalkan kelompok minoritas Syiah Zaydiah yang mempergunakan hukum kewarisan Sunni dan Syiah secara bersamaan.5 Namun secara umum mereka memiliki prinsip yang serupa.

Di samping itu, kajian hukum kewarisan Syiah juga belum mendapatkan tempat khusus di dalam dunia akademik, terutama dalam perguruan tinggi Islam. Kegiatan pembelajaran lebih banyak difokuskan pada hukum kewarisan Sunni serta perwujudannya dalam hukum positif di Indonesia. Belum lagi, terdapat stigma negatif bahkan penolakan secara tegas terhadap kelompok minoritas Syiah di Indonesia oleh sebagian besar masyarakat Muslim baik secara individu atau terorganisasi.6 Padahal, menurut penulis,

3 Jamal J. Ahmad Nasir, The Status of Wonem under Islamic Law and Modern Islamic Legislation, (Leiden: Brill, 2009), 19.

4 Amina Wadud, Qur'an and Woman: Rereading the Sacred Text from a Woman's Perspective, (Oxford: Oxford University Press, 1999), 87-88.

5 Noel J. Coulson, Succession in the Muslim Family, (Cambridge: Cambridge University Press, 1971), 108.

6 Zulkifli, The Struggles of The Shi'is in Indonesia, (Canberra: Autralia University EPress, 2013), 229. 
pemikiran kelompok Syiah pada ranah tertentu justru lebih kontekstual dibandingkan kelompok Sunni.

Bahasan di dalam artikel ini difokuskan pada eksistensi anak perempuan kandung maupun keturunannya di dalam hukum kewarisan Syiah. Tetapi penulis tidak serta-merta melepaskan diri dari hukum kewarisan Sunni. Sebab, pembahasan akan menjadi komprehensif jika ditempuh dengan upaya komparatif. Di samping memang terdapat perbedaan mendasar antara anak perempuan di dalam hukum kewarisan Sunni maupun Syiah. Salah satunya dalam hal kekuatan menghijab. Di satu sisi anak perempuan diperlakukan seakan-akan "orang luar" karena budaya bangsa Arab kala itu mengagungkan ahli waris dari keturunan laki-laki. Namun, di sisi lain anak-baik laki-laki atau perempuan—adalah anggota keluarga yang paling dekat dengan pewaris melebihi ahli waris lainnya. Sehingga, sungguh tidak beralasan kalau perbedaan jenis kelamin menjadi alasan untuk memosisikan anak secara tidak berimbang. Dua sisi dilematis tersebut adalah gambaran dasar perbedaan paradigma hukum kewarisan Sunni dan Syiah.

Terakhir, penulis akan memperbandingkan beberapa aspek prinsipiel dalam hukum kewarisan Syiah dengan hukum kewarisan Sunni yang secara masif diadopsi oleh Instruksi Presiden No. 1 Tahun 1991 tentang Kompilasi Hukum Islam (KHI) sebagai dasar hukum positif di Indonesia. Sehingga bahasan di dalam artikel ini tidak hanya berdimensi fiqbiyyah, tetapi juga menjelajahi tataran qanuniyyah.

\section{Dua Kutub Paradigma Pengelompokan Ahli Waris}

\section{Versi Sunni}

Pengelompokan ahli waris menurut prinsip Syiah atau Sunni memiliki skema yang berbeda. Hukum kewarisan Syiah menggunakan konsep tingkatan atau dapat diistilahkan dengan murtabitah, kelas, dsb. sedangkan term tersebut tidak pernah dikenal dalam hukum kewarisan Sunni. Dalam subbab kali ini, penulis mencoba untuk menyoroti dasar atau landasan kelompok Syiah dalam memahami pengelompokan ahli waris.

Dalam hukum kewarisan Sunni, hak menerima harta warisan kali pertama diberikan kepada mereka yang bagiannya telah ditetapkan di dalam Alquran atau lazim disebut sebagai 
ashab al-furud atau dhaw al-furud. Menurut Hazairin, mereka terdari dari delapan orang:

1. Anak perempuan yang tidak didampingi anak laki-laki, atau oleh mawali untuk mendiang anak laki-laki;

2. Ayah;

3. Ibu;

4. Saudara laki-laki atau perempuan termasuk mendiang saudara perempuan yang memiliki keturunan;

5. Duda; dan

6. Janda.7

Sementara menurut mazhab Hanafi, ahli waris yang tergolong dhaw al-furud, terdiri dari sebelas orang. Mereka adalah:

1. Suami;

2. Istri;

3. Ayah;

4. Kakek;

5. Ibu;

6. Nenek

7. Anak perempuan;

8. Anak perempuan dari anak laki-laki hingga derajat yang paling rendah;

9. Saudara perempuan kandung;

10.Saudara perempuan seayah;

11.Saudara laki-laki/perempuan seibu. 8

Yang kedua, berlanjut kepada ahli waris laki-laki yang memiliki hubungan dengan pewaris tanpa ada perempuan yang menyertai mereka atau lazim disebut asabah. Ahli waris yang tergolong asabah pasti berjenis kelamin laki-laki, tetapi ada keadaan tertentu yang menjadikan perempuan ditarik menjadi

7 Hazairin, Hukum Kewarisan Bilateral menurut Qur'an dan Hadis, (Jakarta: Tintamas, 1982), 56-57.

8 Lucy Carroll, "The Hanafi Law of Intestate Succession: A Simplified Approach", dalam Modern Asian Studies, Vol. 17 No. 4 Oktober 1983, (Cambridge: University of Cambridge, 1983), 636-637. 
asabah dengan syarat ada kesamaan derajat di antara mereka. Misalkan pewaris yang meninggalkan dua ahli waris, yakni anak laki-laki dan anak perempuan. Dalam kasus ini, keberadaan anak laki-laki tersebut menjadikan anak perempuan tadi masuk ke dalam jajaran asabah. Asabah sendiri masih dikategorikan lagi menjadi tiga kelompok, yakni asabah binnafsibi, asabah bilghairi, dan asabah ma'al ghairi.9 Penjelasan asabah secara detailnya akan dibahas dalam subbab berikutnya.

Pemahaman ulama yang seperti demikian berangkat dari pemahaman mereka terhadap hadis Nabi Saw:

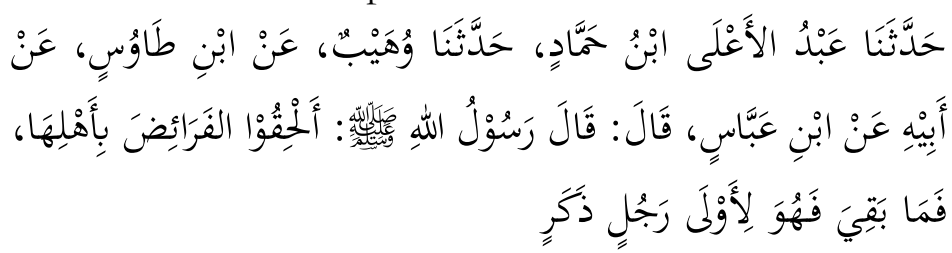

Abdul A'la bin Hammad telah menceritakan kepada kami, dari Wuhaib, dari Ibnu Tawus, dari ayahnya, dari Ibnu Abbas berkata: Rasulullah Saw telah bersabda: berikanlah bagian-bagian yang telah ditetapkan kepada pemiliknya, kemudian selebihnya berikan kepada kerabat laki-laki yang terdekat.10.

Yang ketiga, jika tidak ada ahli waris yang termasuk ke dalam skema dhaw al-furud dan asabah maka warisan diperuntukkan kepada dhaw al-arbam. Secara leksikal maknanya adalah orang-orang yang memiliki hubungan darah. Ahli waris yang tergolong dhaw al-arham pasti berjenis kelamin perempuan atau bisa jadi berjenis kelamin laki-laki tetapi hubungannya dengan pewaris lewat jalur perempuan.11

Terdapat sepuluh ahli waris yang tergolong sebagai dhaw alarham. Mereka adalah:

9 Rachmadi Usman, Hukum Kewarisan Islam dalam Dimensi Kompilasi Hukum Islam, (Bandung: Mandar Maju, 2009), 80.

10 Abu Hasan Muslim al-Naysaburi, Sabih Muslim, (Riyadh: Dar al-Hadarah li alNashr wa al-Tawzi', 2015), 517.

11 Muhammad Abu Zahrah, Hukum Waris Menurut Imam Ja'far Shadiq, terj. Muhamad Alkaf, (Jakarta: Lentera, 1983), 98. 
1. Anak dari anak perempuan;

2. Anaknya saudara perempuan;

3. Anak saudara laki-laki seibu;

4. Anak perempuannya saudara laki-laki;

5. Anak perempuannya paman dari jalur ayah;

6. Paman yang merupakan saudara seibu dengan ayah;

7. Bibi dari jalur ayah (saudara perempuannya ayah);

8. Kakek dari jalur ibu;

9. Paman dan bibi dari jalur ibu.12

Dasar hukum adanya dhaw al-arbam adalah pelaksanaan dari Surat al-Anfal: 75:

Dan orang-orang yang beriman setelah itu, kemudian berbijrah dan beriihad bersamamu maka mereka termasuk golonganmu. Orangorang yang mempunyai bubungan kerabat (ulu al-arbam) satu sama lain berbak (waris-mewaris) menurut Kitab Allah. Sesunggubnya Allab Maba Mengetabui segala sesuatu. 13

Namun ada satu pemahaman yang tidak boleh luput dari pembahasan dhaw al-arbam. Walaupun secara leksikal maknanya adalah kerabat yang memiliki hubungan darah, tetapi menurut sebagian ulama yang merujuk pada hadis yang diriwayatkan oleh Zaid, mereka dianggap sebagai ajnab atau "orang luar". Implikasinya, apabila ada sisa harta yang tidak habis dibagi atau memang benar-benar tidak ada ahli waris golongan dhaw al-furud maupun asabah satu pun yang hidup, maka harta peninggalan pewaris diserahkan pada baitul mal. Argumen ini diperkuat pula oleh Imam Syafi'i dan Imam Malik.14

Penulis menangkap bahwa paradigma ahli waris menurut Sunni lebih menitikberatkan pada aspek jenis kelamin ahli waris tersebut. Terbukti bahwa di luar ahli waris yang menerima bagian pasti (dhaw al-furud), prioritas diberikan kepada ahli waris laki-laki

12 Abu al-Khattab Najm al-Din Mahfud, al-Tadhbib fi al-Fara'id, (Beirut: Dar alKutub al-Ilmiyah, 1998), 163.

13 Kementerian Agama Republik Indonesia, al-Jamil: Alquran dan Terjemabnya, (Bekasi: Cipta Bagu Segara, 2012), 186.

14 Ibid., 164. 
(asabah) dibandingkan ahli waris perempuan atau ahli waris lakilaki yang memiliki kaitan dengan ahli waris perempuan (dhaw alarbam). Bahkan, ada kecenderungan untuk menganggap bahwa dhaw al-arbam itu bukan ahli waris. Mereka adalah orang luar tidak dapat menerima warisan dalam kondisi apa pun. Harta warisan akan tetap diserahkan pada baitul mal walau terdapat dhaw alarbam. Inilah paradigma hukum kewarisan Sunni yang benarbenar menampakkan superioritas laki-laki dibandingkan perempuan.

2. Versi Syiah

Di lain sisi, hukum kewarisan Syiah memiliki paradigmanya tersendiri. Sistem pembagian yang terdiri dari dhaw al-furud, asabah, hingga dhaw al-arham tidak dipakai. Pembagian sematamata didasarkan pada derajat kedekatan atau pertalian darah (blood-tie) antara ahli waris dengan pewaris.15

Di dalam hukum kewarisan Syiah, status sebagai ahli waris dapat diperoleh melalui dua jalan: pertama, mereka yang tergolong ke dalam kelompok al-nasab. Di dalam kelompok alnasab ini diberlakukan sistem kelas. Sedangkan kelompok yang kedua adalah al-sabab. Mereka yang tergolong dalam kelompok alsabab adalah suami/istri yang hidup terlama dan wala'16 Dalam artikel ini, pembahasan hanya difokuskan pada anak perempuan yang ada dalam kelompok al-nasab.

Ulama Syiah memiliki cara lain dalam memahami hukum kewarisan Islam. Surat al-Anfal: 75 (tentang ulu al-arham) justru mereka jadikan prinsip dasar dari berbagai ayat-ayat waris yang ada di dalam Alquran. Sedangkan sudah mafhum di kitab-kitab fikih gubahan ulama Sunni bahwa pembahasan hukum kewarisan Islam selalu bermula dari Surat al-Nisa': 11-12 tentang ahli waris yang menerima bagian pasti (dhaw al-furud).

Meskipun, Surat al-Anfal: 75 sama-sama diamini oleh ulama Sunni maupun Syiah, pemahaman mereka tentang dhaw alarbam atau ulu al-arbam sangat berseberangan. Ulu al-arham oleh

15 Noel J. Coulson, Succession..., 110.

16 Shams al-Din Muhammad ibn Makki, al-Durus al-Syari'ab fi Figh al-Imamiyyah, Juz 2, (Qom: Muassasah al-Nashr al-Islami, 1983), 333. 
ulama Syiah justru dimaknai sebagai kerabat yang dekat dengan pewaris bukan sebagai kerabat jauh yang-bagi sebagian ulama Sunni-bahkan dianggap sebagai ajnab. Mereka berdalil menggunakan ayat ini karena ketika Ali bin Abi Talib mengirimkan surat kepada Muawiyah bin Abi Sofyan bahwa dirinyalah yang layak menyandang jabatan "imam" atau khalifah, ia menggunakan Surat al-Anfal: 75 sebagai dalilnya.17

Sedangkan di dalam kitab Kanz al-Irfan fi Fiqh Alquran memakai redaksi ulu al-arbam sebagai prinsip dasar kewarisan Syiah di dalam ayat yang lain, yakni pada Surat al-Ahzab: 6:

Orang-orang yang memiliki bubungan darah satu sama lainnya berbake (waris-mewarisi) di dalam Kitab Allah daripada orangorang Mubajirin, kecuali kalau kamu hendak berbuat baik. 18

Penulis menangkap bahwa paradigma pengelompokan ahli waris menurut Syiah didasarkan atas derajat/tingkat kedekatan hubungan darah antara pewaris dengan ahli waris, bukan berdasar pada jenis kelamin. Sehingga ahli waris yang berjenis kelamin laki-laki maupun perempuan akan dipandang setara apabila mereka memiliki kedudukan yang seimbang, misalkan antara cucu laki-laki dari anak laki-laki dengan cucu perempuan dengan anak perempuan. Inilah yang kemudian menjadi dasar munculnya sistem kelas di dalam hukum kewarisan Syiah.

\section{Sistem Kelas dalam Hukum Kewarisan Syiah}

Perbedaan terbesar antara Sunni dan Syiah dalam skema pembahasan waris adalah berdasarkan fakta bahwa Syiah menganggap Alquran tidak hanya sebatas wahyu yang mereformasi adat pra-Islam yang mendasarkan waris pada keturunan laki-laki saja. Alquran dalam pandangan mereka melampaui hal tersebut dengan menghadirkan dispensasi atau pengecualian. Semua ahli waris yang memiliki hubungan darah dengan pewaris terintegrasi ke dalam hierarki tunggal mengikat. Prioritas penerima harta waris diberikan kepada ahli waris yang paling dekat dengan pewaris.

17 Muhammad Abu Zahrah, Hukum Waris..., 120.

18 Kementerian Agama Republik Indonesia, al-Jamil..., 418. 
Dalam hal ini, laki-laki atau pun perempuan memiliki derajat yang equal/setara dengan pewarisnya.19

Perbedaan yang mendasar dari sistem kewarisan Sunni adalah tidak ada ahli waris yang dikecualikan atau dihijab semata-mata karena alasan jenis kelamin atau karena dikaitkan dengan ahli waris yang memiliki hubungan dengan pewaris lewat jalur perempuan. Perbedaan kedua adalah prioritas diberikan kepada ahli waris yang masih dalam cakupan nuclear family/keluarga inti pewaris dan keturunannya langsung. Walaupun, pada dasarnya antara laki-laki dan perempuan tetap diberlakukan porsi 2:1. Namun, anak hingga cucu terbawah tetap diprioritaskan dari ahli waris lainnya yang masih berhubungan darah dengan pewaris.20

Berikut, tabel hierarki/kelas ahli waris dalam hukum kewarisan Syiah yang terbagi menjadi tiga:

\begin{tabular}{|l|l|}
\hline Kelas/Murtabitab I & $\begin{array}{l}\text { a. Orang tua } \\
\text { b. Anak dan keturunannya atau cucunya } \\
\text { hingga derajat yang paling rendah }\end{array}$ \\
\hline $\begin{array}{l}\text { Kelas/Murtabitah } \\
\text { II }\end{array}$ & $\begin{array}{l}\text { a. Kakek-nenek dan para pendahulunya } \\
\text { sampai ke derajat yang paling tinggi } \\
\text { b. Garis menyamping, yakni saudara (laki- } \\
\text { laki, perempuan, kandung, seayah, } \\
\text { maupun seibu), kemudian keturunannya. }\end{array}$ \\
\hline $\begin{array}{l}\text { Kelas/Murtabitah } \\
\text { III }\end{array}$ & $\begin{array}{l}\text { a. Paman dan bibi dari keluarga ayah } \\
\text { maupun ibu kemudian keturunannya. } \\
\text { b. Saudara kakek-nenek kemudian } \\
\text { keturunannya. }\end{array}$ \\
\hline
\end{tabular}

Di dalam Kelas I, orang tua dan anak-anak kandung mewarisi harta warisan secara bersamaan. Tidak ada satu pun keturunan dari

19 Lucy Carroll, "The Ithna Ashari Law of Intestate Succession: An Introduction to Shia Law Applicable in South Asia", Modern Asian Studies, Vol. 19 No. 1 Februari, 1985, (Cambridge: University of Cambridge, 1985), 86.

20 Ibid. 
pewaris yang dapat terhijab21 akibat kehadiran orang tua. Begitu pula orang tua yang selamanya tidak akan pernah terhijab oleh kehadiran keturunan pewaris. Tetapi, keturunan pewaris (anak atau cucu) yang paling dekat atau yang paling tinggi derajatnya baik itu laki-laki atau perempuan tidak hanya mampu menghijab keturunan yang derajatnya lebih rendah, ia juga mampu menutup pintu untuk anggota keluarga yang lainnya.22 Sebagai contoh, anak perempuannya anak perempuan (cucu perempuan) akan menghijab anak laki-lakinya cucu laki-laki (cicit laki-laki) karena derajatnya cucu perempuan tadi adalah keturunan yang lebih dekat dengan pewaris dibandingkan dengan cicit laki-laki. Cucu perempuan tersebut juga menghijab anggota keluarga lainnya

Kemudian di dalam Kelas II terdapat kakek-nenek23 dan saudara laki-laki atau perempuan (kandung, seibu, atau seayah) beserta keturunannya saudara tersebut. Kakek-nenek dari jalur ibunya pewaris maupun dari ayahnya pewaris menempati derajat yang setara. Artinya, bukan berarti prioritas ada pada kakek-nenek yang berasal dari jalur laki-laki (ayahnya pewaris). Mereka mewaris bersama-sama. Sebagaimana penjelasan sebelumnya, kakek-nenek yang lebih dekat dengan pewaris akan menghijab kakek-nenek yang di atasnya. 24

Selanjutnya, jika ada saudara laki-laki atau perempuan (kandung, seayah, dan seibu) maka keturunan mereka terhijab

21 Penggunaan kata hijab-menghijab di dalam artikel ini bermakna menutup atau mengecualikan secara total. Penulis tidak menggunakan istilah hijab hirman dan hijab nuqshan. Penulis cukup memakai frasa "mengurangi bagian" atau semacamnya jika memang ada ahli waris yang porsinya harus dikurangi akibat kehadiran ahli waris lainnya. Sebab pada dasarnya pengurangan porsi bukan berarti terhijab atau tertutup untuk menerima harta warisan. Hal tersebut hanya wujud penyesuaian dan penyeimbangan porsi antar ahli waris yang sama-sama berhak menerima bagian harta warisan.

22 Lucy Carroll, “The Ithna Ashari Law of Intestate Succession...”, 87.

23 Penulisan "kakek-nenek" dimaksudkan bahwa mereka pasti mewaris bersama. Berbeda dengan saudara yang masih terbuka peluang untuk tidak mewaris bersama akibat hubungan darah yang berlainan, misalkan saudara kandung akan menghijab saudara seayah.

24 Shams al-Din Muhammad ibn Makki, al-Lum'ab al-Dimasyqiyyah fi Fiqh Imamiyyah, (Beirut: Dar al-Islamiyah, 1990), 156. 
karena saudara posisinya lebih dekat dengan pewaris daripada anaknya saudara (kemenakan). Saudara laki-laki atau perempuan kandung dapat menghijab saudara laki-laki atau perempuan seayah. Namun, saudara laki-laki atau perempuan seibu tidak dapat menghijab maupun dihijab oleh saudara laki-laki atau perempuan kandung maupun seayah. Dan antara saudara dengan kakek-nenek tidak dapat saling hijab-menghijab karena mereka mewaris bersama.

Terakhir, di Kelas III terdapat paman atau bibi (kandung, seayah, atau seibu) beserta keturunannya. Kemudian ada saudaranya kakek-nenek dan keturunannya. Sebagaimana ketentuan yang sebelumnya, anggota keluarga yang dekat akan menghijab anggota keluarga yang lebih jauh, misalkan terdapat paman dan anaknya, maka yang mendapatkan warisan adalah pamannya.

Terkait paman atau bibi tersebut kandung, seayah atau seibu, ketentuannya berlaku sebagaimana penjelasan hubungan saudara di Kelas II. Tidak ada preferensi antara paman atau bibi dari jalur ayah atau dari jalur ibu, hanya bagiannya saja yang sedikit berbeda.25 Di antara paman atau bibi dari satu jalur yang sama—misalkan dari jalur ayah pewaris_-yang statusnya kandung akan menghijab yang seayah namun, yang seibu tetap tidak dapat terhijab atau menghijab yang kandung atau seayah. Menariknya, paman atau bibi seibu juga tidak akan menghijab atau terhijab oleh paman atau bibi kandung maupun seayah yang berada di jalur lain—dari jalur ibu pewaris.26

\section{Kontradiksi Konsep Asabah}

\section{Konsep Asabah Sunni}

Adanya ketentuan ahli waris yang mendapat bagian seluruh harta atau sisa harta secara pembagian terbuka, yang pada umumnya adalah laki-laki, dikembangkan kepada ahli waris lakilaki lain yang tidak disebutkan dalam Alquran atau hadis Nabi. Anak laki-laki dikembangkan kepada cucu laki-laki; ayah dikembangkan kepada kakek atau kepada paman dan anaknya

25 Asaf Ali Asghar Fyzee, Outlines of Mubammadan Law, (Oxford: Oxford University Press, 2009), 361.

26 Lucy Carroll, “The Ithna Ashari Law of Intestate Succession...”, 88. 
paman; saudara dikembangkan kepada anak saudara; hingga lengkap sudah kerabat dalam garis laki-laki.27

Kelompok kerabat garis laki-laki ini dalam Bahasa Arab disebut sebagai asabah, Oleh karena yang berhak atas seluruh harta atau sisa harta waris menurut aliran Sunni pada dasarnya adalah laki-laki. Tidak ada ketentuan bagian pasti yang mereka dapatkan sebagaimana dalam kelompok ahli waris dhaw al-furud. Namun, kekerabatan itu pastinya bertingkat-tingkat dari segi keutamaannya. Sehingga, hanya asabah yang levelnya paling tinggi atau yang paling dekat dengan pewarislah yang berhak mendapatkan harta.28

Asabah sendiri dikategorikan menjadi tiga kelompok. Kelompok pertama adalah asabah bi nafsibi yang merupakan semua kerabat laki-laki pewaris tanpa adanya selingan perempuan di dalamnya. Mereka terdiri dari:

1. Anak laki-laki;

2. Cucu laki-laki dari anak laki-laki;

3. Ayah;

4. Ayahnya ayah (kakek);

5. Saudara kandung;

6. Saudara seayah;

7. Anak laki-laki saudara kandung;

8. Anak laki-laki saudara seayah;

9. Paman yang sekandung dengan ayah;

10. Paman yang seayah dengan ayah;

11. Anak laki-laki dari paman yang sekandung dengan ayah;

12. Anak laki-laki dari paman yang seayah dengan ayah.29

Apabila ada kerabat laki-laki tersebut keberadaannya diselingi oleh perempuan, maka ia tidak tergolong asabah dan dianggap sebagai kerabat jauh atau dhawil arbam. Misalkan seperti cucu laki-laki yang lahir dari seorang anak perempuan pewaris.

27 Amir Syarifuddin, Hukum Kewarisan Islam, (Jakarta: Kencana, 2008), 232.

28 Ibid.

29 Muhammad Ma'shum Zein, Figh Mawarist: Studi Metodologi Hukum Kewarisan Islam, (Jombang: Darul Hikmah, 2008), 95. 
Faby Toriqirrama: Eksistensi Anak Perempuan......

Atau kakek tetapi ditarik dari garis ibu pewaris. Terkecuali saudara laki-laki seibu yang termasuk dhaw al-furud atau orangorang yang mendapatkan bagian pasti. Sebab, eksistensinya termaktub di dalam Alquran.

Sedangkan yang kedua adalah asabah bi al-ghair. Mereka adalah setiap ahli waris perempuan yang ikut serta dalam jajaran asabah jika mewaris bersama ahli waris laki-laki. Mereka terdiri dari:

1. Anak perempuan kandung;

2. Cucu perempuan dari anak laki-laki;

3. Saudara perempuan sekandung;

4. Saudara laki-laki seayah.30

Sebelum menjadi asabah bi al-ghair keempat ahli waris tersebut harus memiliki posisi dan kekerabatan yang sama dengan ahli waris yang akan meng-asabah-kan mereka. Misalkan, pewaris meninggalkan dua orang anak kandung-satu perempuan dan satu laki-laki. Anak perempuan tersebut, yang awal mulanya merupakan dhaw al-furud dan memperoleh $1 / 2$ bagian harta, ditarik menjadi asabah bi al-ghair oleh anak laki-laki sebab antara keduanya memiliki kedudukan dan kekerabatan yang sama kuat di hadapan pewaris. Andaikan pewaris meninggalkan harta warisan sebanyak Rp 90.000.000, maka anak perempuan tersebut yang seyogianya menerima 45 juta atau separuhnya. Namun, karena menjadi asabah bi al-ghair, bagiannya terkoreksi menjadi 30 juta karena antara laki-laki dan perempuan diberlakukan ketentuan 2:1.

Yang terakhir adalah asabah ma'a al-ghair yang definisinya adalah tiap-tiap ahli waris perempuan yang menjadi asabah sebab adanya ahli waris perempuan lainnya. Secara konkret, jika saudara perempuan—sekandung ataupun seayah-mewaris bersama anak perempuan maka ia menjadi asabah ma'a al-ghair. Dengan keadaan yang demikian, maka saudara perempuan yang menjadi asabah ma'a al-ghair memiliki kekuatan menghijab sebagaimana saudara laki-laki. Misalkan, saudara perempuan kandung yang menjadi asabah ma'a al-ghair dapat menghijab saudara laki-laki

30 Ibid., 103. 
seayah dan saudara perempuan seayah. Sedangkan saudara perempuan seayah mampu menghijab anak laki-laki dari saudara laki-laki kandung dan anak laki-laki dari saudara laki-laki seayah.31

\section{Penolakan terhadap Konsep Asabah Sunni}

Konsep asabah umumnya dikenal dalam hukum kewarisan Sunni sebagaimana penjelasan di subpoin sebelumnya. Tetapi di dalam hukum kewarisan Syiah, seorang ahli waris berhak menerima harta atau menjadi bagian dalam daftar ahli waris bukan semata-mata didasarkan pada jenis kelamin. Semua ahli waris, baik itu laki-laki atau perempuan terintegrasi ke dalam sistem kelas yang didasarkan pada skala kedekatan antara pewaris dengan ahli waris.32

Penolakan konsep asabah, menurut penulis, adalah implikasi dari paradigma qarabah yang menjadi basis hukum kewarisan Syiah. Cara pandang mereka terhadap ahli waris bukan berangkat dari jenis kelamin tetapi seberapa dekat mereka dengan pewaris. Sehingga, selama ahli waris laki-laki dan perempuan memiliki hubungan yang sama-sama dekat dengan pewaris, mereka memiliki derajat yang sama dan yang memiliki hubungan kekerabatan yang berbeda, maka ahli waris terdekat akan dimenangkan, sebagai mana kutipan berikut:

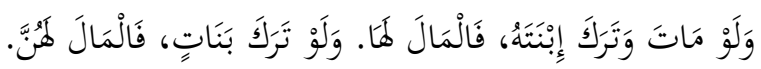

Apabila (pewaris) wafat dan meninggalkan seorang anak perempuan, maka selurub harta warisannya untuk seorang anak. perempuan tersebut. Apabila (pewaris) wafat dan meninggalkan beberapa anak perempuan, maka selurub harta warisannya untuk. beberapa anak perempuan tersebut.33

31 Ibid., 109.

32 Lucy Carroll, "The Ithna Ashari Law of Intestate Succession...", 89. 33 Samahah Ayatulllah al-Mashkini, al-Figh al-Ma'thur wa al-Usul al-Mutalaqqah, (alHadi': Daftar Nashr al-Hadi', 1989), 389. 


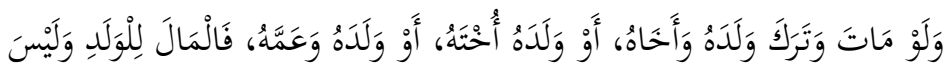

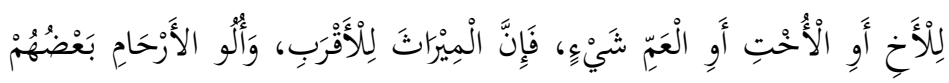

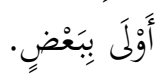

Apabila (pewaris) wafat dan meninggalkan seorang anak (laki-laki atau perempuan) 34 bersama saudara laki-laki, atau seorang anak bersama saudara perempuan, atau seorang anak bersama paman, maka selurub harta warisanny antuk anak saja dan tidak untuk saudara laki-laki, saudara perempuan, atau paman. Sebab, yang dinamakan waris itu adalab untuk kerabat dekat (qarabab) yang derajat pertalian darahnya lebih utama/ tinggi dibandingkan abli waris lainnya. 35

Dua kutipan di atas sebetulnya sudah cukup memberikan ulasan representatif bahwa jika hanya ada satu atau beberapa anak perempuan, maka semua hartanya akan diberikan kepada mereka. Dalam hal ini, kedudukan perempuan tidak hanya sebagai dhaw al-furud, tetapi sekaligus penerima sisa harta. Ia seakan-akan berposisi menjadi anak laki-laki di dalam hukum kewarisan Sunni. Kemudian kutipan selanjutnya memberikan aksentuasi bahwa walaupun ada ahli waris laki-laki (asabah) yang diagungkan dalam hukum kewarisan Sunni-justru dengan sendirinya akan terhijab secara mutlak oleh kehadiran anak laki-laki atau anak perempuan. Sebab, antara anak dengan paman dan saudara pewaris berada dalam kelas yang berbeda. Anak menempati posisi the highest rank. Tentu, kasta tertinggi akan mengesampingkan kasta di bawahnya.

Bagi penulis, sinisme para intelektual yang mengatakan bahwa di dalam hukum kewarisan Islam, perempuan ditempatkan sebagai manusia sekunder dengan sendirinya terbantahkan oleh adanya sistem kelas yang dianut oleh kelompok Syiah. Perempuan dan laki-laki memiliki derajat yang setara di mata pewaris.

34 Pemaknaan "walad" dalam hal ini tidak terbatas pada "anak laki-laki kandung" saja tetapi juga mencakup "anak perempuan kandung". Baca Muhammad Abu Zahrah, Hukum Waris..., 129.

35 Ibid. 
Selain itu, agaknya telah terjadi hegemoni ilmu pengetahuan di lingkungan perguruan tinggi agama Islam bahwa selama ini, rujukan perkuliahan yang bersangkut paut dengan fikih (perkawinan, kewarisan, ushul fikih, dsb) selalu merujuk pada kitab-kitab karangan ulama Sunni, terutama ulama yang bermazhab Hanafi, Maliki, Syafi'i, dan Hanbali. Sedangkan ulama Syiah seperti Muhammad Husain Tabathaba'i atau Murtadha Mutahhari, seakan termarginalisasi bahkan tidak dikenali.

\section{Kekuatan Menghijab Anak Perempuan Kandung serta Keturunannya antara Sunni dan Syiah}

Keistimewaan pengelompokan ahli waris di dalam hukum kewarisan Syiah adalah adanya kesetaraan antara laki-laki dengan perempuan. Sehingga, hal ini secara tidak langsung menjadi oposisi dari hukum kewarisan Sunni yang memberikan prioritas kepada ahli waris laki-laki. Meski demikian, laki-laki tetap akan mewarisi dua kali bagian ahli waris perempuan-konsep yang sama dalam hukum kewarisan Sunni. Namun ilustrasi berikut akan menunjukkan, walau masih mengadopsi sistem 2:1, tetapi tetap ada perbedaan yang penulis nilai masih lebih adil dibandingkan versi Sunni.

Ilustrasi:

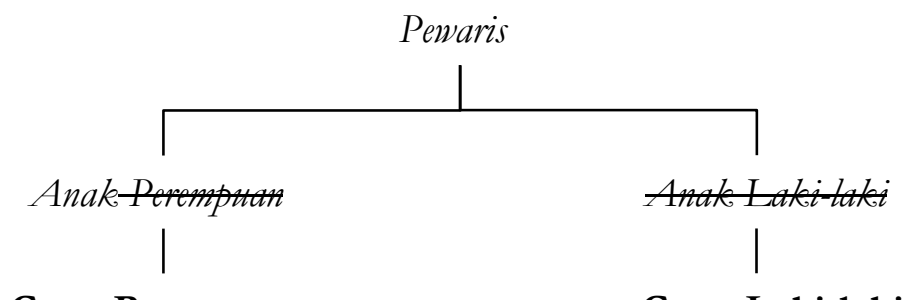

\section{Cucu Perempuan}

Cucu Laki-laki

Misalkan pewaris hanya meninggalkan cucu perempuan dari anak perempuan dan cucu laki-laki dari anak laki-laki. Jika mengacu pada hukum kewarisan Sunni, cucu perempuan dari anak perempuan itu akan terhijab oleh keberadaan cucu laki-laki yang berposisi sebagai asabah. Alasannya adalah cucu perempuan tadi berdiri sebagai dhaw al-arbam atau kerabat jauh dalam konsep Sunni. Dhaw al-arbam baru akan mendapatkan harta warisan apabila tidak 
ada sama sekali ahli waris dari golongan dhaw al-furud maupun asabah. Di dalam hukum kewarisan Syiah, tidak ada perbedaan antara kedua ahli waris tersebut. Dua-duanya tetap mendapatkan harta warisan dengan porsi 2:1. Dua-duanya dipandang setara sebagai cucu dari pewaris. Tidak ada ketentuan apakah cucu perempuan tadi lahir dari garis keturunan laki-laki (agnatic heir) atau perempuan. Inilah salah satu kelebihan hukum kewarisan Syiah.

Berikut, penulis sajikan gambaran lain yang menunjukkan kekuatan keluarga inti yang ada di dalam Kelas I untuk menghijab anggota keluarga yang lain. Dalam contoh ini akan terlihat jelas bahwa hukum kewarisan Syiah memang memprioritaskan perempuan, terutama jika ia adalah anak. Pewaris telah wafat dan ia meninggalkan seorang anak perempuan serta saudara laki-laki kandung.

Ilustrasi:
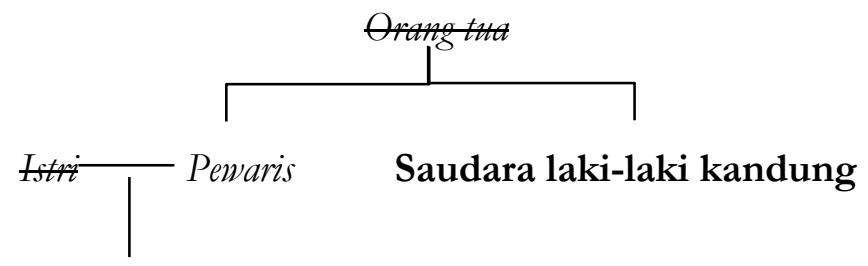

\section{Anak Perempuan}

Misalkan Pewaris meninggalkan harta warisan sebesar Rp 100.000.000 dan ahli waris yang hidup hanya anak perempuan dan saudara laki-laki kandung. Jika mengacu pada ketentuan faraid-nya Sunni maka anak perempuan hanya mendapat $1 / 2$ bagian dan setengahnya lagi akan diberikan kepada saudara laki-laki kandung karena ia berdiri sebagai asabah atau ahli waris yang tidak mendapat bagian pasti. Anak perempuan selamanya tidak akan mendapatkan seluruh harta pewaris walau ia menjadi pewaris tunggal. Bagian terbesar yang dapat ia terima hanyalah $1 / 2$. Ia masih mungkin menjadi asabah tetapi dengan syarat ada anak laki-laki. Tetapi pada akhirnya, ia tetap menerima bagian yang lebih sedikit dibandingkan anak lakilaki. Di sinilah posisi anak perempuan yang tidak terlalu diprioritaskan dalam hukum kewarisan Sunni.

Sedangkan jika mengacu pada hukum kewarisan Syiah, maka anak perempuan akan memperoleh keseluruhan bagian, atau $1 / 2$ plus 
rad-nya karena tidak adanya ahli waris lain dalam Kelas I. Jika ada satu saja ahli waris di Kelas I yang masih hidup, ia akan mewarisi seluruh harta pewaris dan mengecualikan ahli waris lain yang berada di Kelas II terlebih Kelas III.

\section{Dialektika Kewarisan Anak Perempuan di dalam Kompilasi Hukum Islam}

Tentu kurang akurat kalau membahas hukum Islam dipandang dari sisi fikihnya saja, perlu juga dipandang dari segi hukum positifnya. Oleh karenanya, penulis menjadikan Inpres No. 1 Tahun 1991 tentang Kompilasi Hukum Islam (KHI) sebagai objek materiel analisis. Sebab ini adalah satu-satunya hukum positif yang berisi ketentuan waris bagi umat Muslim di Indonesia.

Sebagaimana uraian sebelumnya, terdapat dua prinsip dasar dalam hukum kewarisan Syiah. Pertama adalah prinsip hubungan kerabat yang diorganisasi dalam sistem kelas. Selama ada satu atau lebih ahli waris yang hidup di Kelas I, maka ahli waris yang berada di Kelas II dan Kelas III tidak akan menerima bagian sedikit pun. Namun, jika tidak ada satu orang ahli waris pun di Kelas I maka ahli waris di kelas II akan mengambil posisinya dan ahli waris di Kelas III akan terhijab dan seterusnya.36 Kemudian yang kedua adalah prinsip kesetaraan antara ahli waris laki-laki dan perempuan, namun rasio 2:1 tetap diberlakukan.

Apakah prinsip tersebut diadopsi di dalam KHI, walaupun KHI masih mengadopsi hukum kewarisan Sunni? Sejauh penelusuran penulis memang tidak dikenal konsep kelas di dalam KHI. Tetapi, ada kemiripan visi antara KHI dengan hukum kewarisan Syiah khusus terkait anak perempuan.

Di dalam Pasal 176 KHI dalam Bab III Besarnya Bagian Waris tertulis:

"Anak perempuan bila hanya seorang ia mendapat separuh bagian, bila dua orang atau lebih, mereka bersama-sama mendapat dua pertiga bagian, dan apabila anak perempuan

${ }_{36}$ Shahbaz Ahmad Cheema, "Shia and Sunni Laws of Inheritance: A Comparative Analysis", dalam Pakistan Journal of Islamic Research, Vol. 10 2012, (Lahore: University of Punjab, 2012), 71. 
bersama anak laki-laki, maka bagian anak laki-laki adalah dua banding satu bagian anak perempuan."

Tampak di dalam pasal tersebut menjelaskan sesuai dengan ketentuan faraid yang apa adanya di dalam hukum kewarisan Sunni. Dalam hal ini, KHI mengadopsi penuh ketentuan tentang bagian anak perempuan sebagaimana termaktub di dalam Surat al-Nisa: 11 yang menjelaskan secara detail:

Dan jika anak itu semuanya perempuan yang jumlabnya lebib dari dua, maka bagian mereka dua pertiga dari harta yang ditinggalkan, jika dia (anak perempuan) hanya seorang saja maka ia memperoleh setengah (dari harta yang ditinggalkean). 37

Kemudian, beralih ke Pasal 181:

"Bila seorang meninggal tanpa meninggalkan anak dan ayah, maka saudara laki-laki dan saudara perempuan seibu masingmasing mendapat seperenam bagian. Bila mereka itu dua orang atau lebih maka mereka bersama-sama mendapat sepertiga bagian."

Dan juga Pasal 182:

"Bila seorang meninggal tanpa meninggalkan ayah dan anak sedang ia mempunyai satu saudara perempuan kandung atau seayah, maka ia mendapat separuh bagian..."

Kedua pasal tersebut tidak mencantumkan frasa anak perempuan atau anak laki-laki secara khusus yang menjadi alasan saudara laki-laki atau saudara perempuan seibu mendapatkan bagiannya (Pasal 181). Kemudian di Pasal 182 juga tidak disebut frasa anak perempuan atau anak laki-laki secara khusus yang menjadi alasan saudara perempuan kandung atau seayah mendapatkan bagiannya. Sehingga, kata "anak" di dalam Pasal 181 atau 182 maknanya adalah anak perempuan atau anak laki-laki. Anak perempuan dan anak laki-laki di dalam KHI diposisikan setara. Maka anak perempuan juga mempunyai kekuatan menghijab sebagaimana sistem Kelas di dalam hukum kewarisan Syiah. Anak perempuan berada di Kelas I sehingga ia mampu menghijab segala jenis saudara pewaris yang berada di Kelas II.

37 Kementerian Agama Republik Indonesia, al-Jamil..., 78. 
Dapat disimpulkan di sini bahwa prinsip dasar hukum kewarisan Syiah yang penulis sebutkan sebelumnya diadopsi oleh KHI, khususnya yang terkait dengan anak perempuan. Anak perempuan mampu menghijab segala jenis saudara sebab ia diposisikan sejajar dengan anak laki-laki. Walau KHI tidak secara eksplisit mengadopsi sistem Kelasnya Syiah, namun rumusan pasalnya cukup memberikan gambaran bahwa nilai-nilai kesetaraan di dalam hukum kewarisan Syiah, tercermin di dalam KHI.

\section{Penutup}

Stigma bias gender yang sering dinisbahkan pada hukum kewarisan Islam ternyata tidak sepenuhnya tepat. Di dalam hukum kewarisan Syiah ahli waris perempuan diberkahi dengan muruah. Mereka mampu berdiri sejajar dengan ahli waris laki-laki. dalam paper ini, penulis menyoroti eksistensi anak perempuan. Menurut Sunni, ahli waris laki-laki lebih aula (diutamakan) dibandingkan ahli waris perempuan. Tetapi menurut Syiah, justru ahli waris yang memiliki hubungan darah terdekat dengan pewaris lah yang harus diutamakan. Paradigma ini pada akhirnya menciptakan sistem Kelas. Di dalam sistem tersebut, anak perempuan mendapatkan prioritas utama dan mampu menghijab segala jenis saudara. Suatu hal yang tidak ditemukan di dalam hukum kewarisan Sunni. Selain itu, Pasal 181 dan 182 KHI menjadi bukti bahwa ternyata KHI mengadopsi prinsip hukum kewarisan Syiah meskipun tidak secara terangterangan menggunakan sistem Kelas.

\section{Daftar Pustaka}

Abd Wahab Khalaf. Ilm Ushul al-Fiqh, Jakarta: Dar al-Kutub alIslamiyah, 2010.

Abu al-Khattab Najm al-Din Mahfud. al-Tadhbib fi al-Fara'id, Beirut: Dar al-Kutub al-Ilmiyah, 1998.

Abu Hasan Muslim al-Naysaburi. Sabih Muslim, Riyadh: Dar alHadarah li al-Nashr wa al-Tawzi', 2015.

Amina Wadud. Qur'an and Woman: Rereading the Sacred Text from a Woman's Perspective, Oxford: Oxford University Press, 1999. Amir Syarifuddin, Hukum Kewarisan Islam, Jakarta: Kencana, 2008. Asaf Ali Asghar Fyzee. Outlines of Mubammadan Law, Oxford: Oxford University Press, 2009. 
Faby Toriqirrama: Eksistensi Anak Perempuan......

Hazairin, Hukum Kewarisan Bilateral menurut Qur'an dan Hadis. Jakarta: Tintamas, 1982.

Jamal J. Ahmad Nasir. The Status of Wonem under Islamic Law and Modern Islamic Legislation, Leiden: Brill, 2009.

Kementerian Agama Republik Indonesia. al-Jamil: Alquran dan Terjemahnya, Bekasi: Cipta Bagu Segara, 2012.

Lucy Carroll. "The Hanafi Law of Intestate Succession: A Simplified Approach", dalam Modern Asian Studies, Vol. 17 No. 4 Oktober 1983, Cambridge: Cambridge University Press, 1983.

------. "The Ithna Ashari Law of Intestate Succession: An Introduction to Shia Law Applicable in South Asia", dalam Modern Asian Studies, Vol. 19 No. 1 Februari, 1985, Cambridge: Cambridge University Press, 1985.

Muhammad Abu Zahrah. Hukum Waris Menurut Imam Ja'far Shadiq, terj. Muhamad Alkaf, Jakarta: Lentera, 1983.

Muhammad Ma'shum Zein. Fiqh Mawarist: Studi Metodologi Hukum Kewarisan Islam, Jombang: Darul Hikmah, 2008.

Noel J Coulson. Succession in the Muslim Family, Cambridge: Cambridge University Press, 1971.

Rachmadi Usman. Hukum Kewarisan Islam dalam Dimensi Kompilasi Hukum Islam, Bandung: Mandar Maju, 2009.

Samahah Ayatulllah al-Mashkini. al-Figh al-Ma'thur wa al-Usul alMutalaqqah, al-Hadi': Daftar Nashr al-Hadi', 1989.

Shahbaz Ahmad Cheema. "Shia and Sunni Laws of Inheritance: A Comparative Analysis", dalam Pakistan Journal of Islamic Research, Vol. 10 2012, Lahore: University of Punjab, 2012.

Shams al-Din Muhammad ibn Makki. al-Durus al-Syari ah fi Fiqh alImamiyyah, Juz 2, Qom: Muassasah al-Nashr al-Islami, 1983. -. al-Lum'ah al-Dimasyqiyyah fi Fiqh Imamiyyah, Beirut: Dar alIslamiyah, 1990.

Zulkifli. The Struggles of The Shi'is in Indonesia, Canberra: Autralia University E-Press, 2013. 